Prepared in cooperation with the Bonneville Power Administration and Public Utility District Number 1 of Lewis County, Washington

\title{
Behavior and Survival of Hatchery Rainbow Trout (Oncorhynchus mykiss) in the Upper Cowlitz River Basin, Washington, 2013 and 2017
}

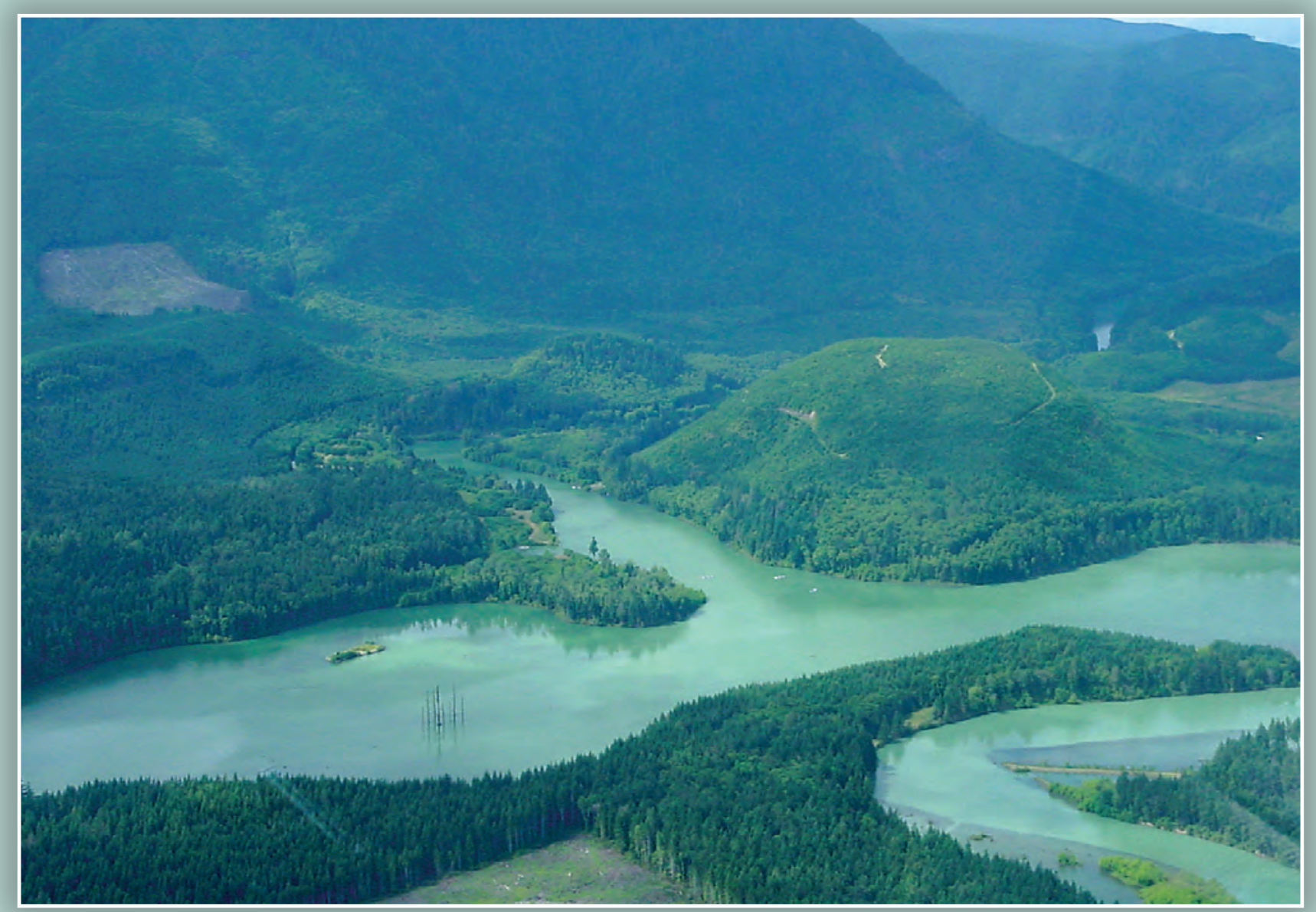

Open-File Report 2021-1085

Version 1.1, September 2021 
Cover. Looking southwest at the confluence of Lake Scanewa and the Cowlitz and Cispus Rivers, Washington. Photograph by John Serl, Washington Department of Fish and Wildlife, July 7, 2005. 


\section{Behavior and Survival of Hatchery Rainbow Trout (Oncorhynchus mykiss) in the Upper Cowlitz River Basin, Washington, 2013 and 2017}

By Amy C. Hansen, Tobias J. Kock, Brian K. Ekstrom, and Theresa L. Liedtke

Prepared in cooperation with the Bonneville Power Administration and Public Utility District Number 1 of Lewis County, Washington

Open-File Report 2021-1085

Version 1.1, September 2021 


\section{U.S. Geological Survey, Reston, Virginia: 2021}

For more information on the USGS - the Federal source for science about the Earth, its natural and living resources, natural hazards, and the environment—visit https://www.usgs.gov or call 1-888-ASK-USGS.

For an overview of USGS information products, including maps, imagery, and publications, visit https://store.usgs.gov/.

Any use of trade, firm, or product names is for descriptive purposes only and does not imply endorsement by the U.S. Government.

Although this information product, for the most part, is in the public domain, it also may contain copyrighted materials as noted in the text. Permission to reproduce copyrighted items must be secured from the copyright owner.

Suggested citation:

Hansen, A.C., Kock, T.J., Ekstrom, B.K., and Liedtke, T.L., 2021, Behavior and survival of hatchery rainbow trout (Oncorhynchus mykiss) in the upper Cowlitz River Basin, Washington, 2013 and 2017 (ver. 1.1, September 2021): U.S. Geological Survey Open-File Report 2021-1085, 14 p., https://doi.org/10.3133/ofr20211085.

ISSN 2331-1258 (online) 


\section{Acknowledgments}

We thank Mike Kohn (formerly with Lewis County Public Utility District) for initiating these research efforts and Debbie Carlson with Bonneville Power Administration for managing the contracting for them. Laura Wolf (Lewis County Public Utility District) assisted with coordination for the reporting effort. We thank John Serl (Washington Department of Fish and Wildlife) and Wade Heimbigner (Pacific States Marine Fisheries Commission) for collection of rainbow trout in 2013 and their extensive knowledge of the upper Cowlitz Basin. We thank numerous private landowners in the upper Cowlitz River Basin who provided access for fixed telemetry sites and mobile tracking. Nicole Ogan (Blue Leaf Environmental) supported tagging efforts in June of 2017.

We appreciate Ryan Tomka (U.S. Geological Survey) and William Hurst (formerly of the U.S. Geological Survey) for their contribution with field efforts, especially tagging, downloading, and mobile tracking. Finally, we thank our colleagues at the U.S. Geological Survey Columbia River Research Laboratory for their efforts with fieldwork during the study. 


\section{Contents}

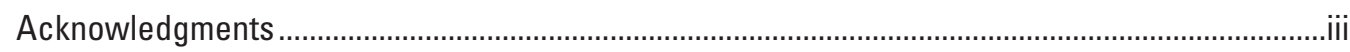

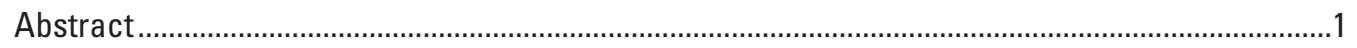

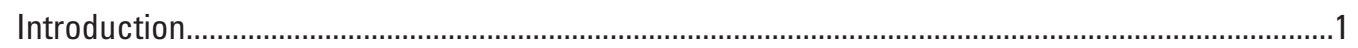

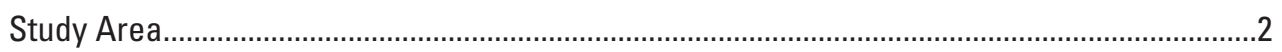

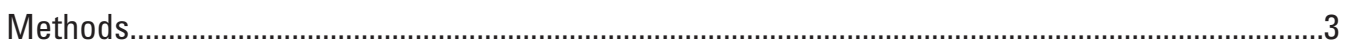

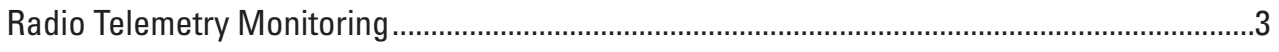

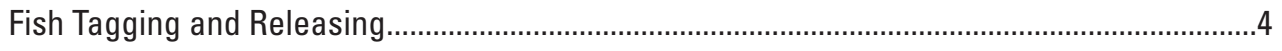

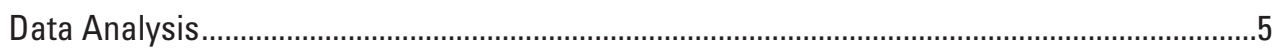

Evaluation of Spawning Overlap with Steelhead ..................................................................

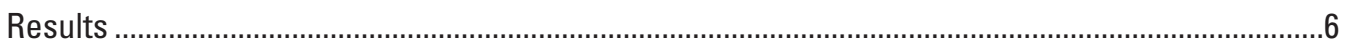

Evaluation of Spawning Overlap with Steelhead …………...................................................

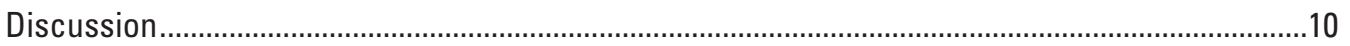

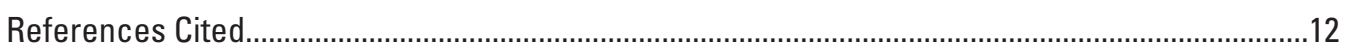

\section{Figures}

1. Map showing locations of fixed radio telemetry monitoring sites used only in 2013, fixed radio telemetry sites used in 2013 and 2017, fixed radio telemetry sites used in 2017, and locations where radio-tagged rainbow trout were released, upper Cowlitz River Basin, Washington

2. Graph showing radio-tagged hatchery rainbow trout fork lengths by date and release location in the upper Cowlitz River Basin, Washington, 2013 and 2017

3. Graph showing percentage of radio-tagged rainbow trout by maximum distance moved from release site in the upper Cowlitz River Basin, Washington, 2013 and 2017.

4. Stacked bar graph showing number of radio-tagged rainbow trout, by date and release month, entrained at the Cowlitz Falls Dam and line graph showing discharge at Cowlitz Falls Dam in the upper Cowlitz River Basin, Washington, 2013 and 2017.

5. Graph showing apparent survival apparent survival of radio-tagged rainbow trout, in days by year of release, in the upper Cowlitz River Basin, Washington, 2013 and 2017.

\section{Tables}

1. Number and size of hatchery rainbow trout tagged and released, by month of release, in the upper Cowlitz River Basin, Washington, 2013 and 2017

2. Percentage of fish and their fate, by year of release, in the upper Cowlitz River Basin, Washington, 2013 and 2017. 


\section{Conversion Factors}

U.S. customary units to International System of Units

\begin{tabular}{ccc}
\hline Multiply & By & To obtain \\
\hline & Flow rate & \\
\hline cubic foot per second $\left(\mathrm{ft}^{3} / \mathrm{s}\right)$ & 0.02832 & cubic meter per second $\left(\mathrm{m}^{3} / \mathrm{s}\right)$ \\
\hline
\end{tabular}

International System of Units to U.S. customary units

\begin{tabular}{|c|c|c|}
\hline Multiply & By & To obtain \\
\hline \multicolumn{3}{|c|}{ Length } \\
\hline centimeter $(\mathrm{cm})$ & 0.3937 & inch (in.) \\
\hline river kilometer (rkm) & 0.3107 & mile (mi) \\
\hline \multicolumn{3}{|c|}{ Area } \\
\hline hectare (ha) & 2.471 & acre \\
\hline square kilometer $\left(\mathrm{km}^{2}\right)$ & 247.1 & acre \\
\hline hectare (ha) & 0.003861 & square mile $\left(\mathrm{mi}^{2}\right)$ \\
\hline square kilometer $\left(\mathrm{km}^{2}\right)$ & 0.3861 & square mile $\left(\mathrm{mi}^{2}\right)$ \\
\hline \multicolumn{3}{|c|}{ Volume } \\
\hline liter (L) & 33.81402 & ounce, fluid (fl. oz) \\
\hline liter (L) & 2.113 & pint (pt) \\
\hline liter (L) & 1.057 & quart (qt) \\
\hline \multicolumn{3}{|c|}{ Mass } \\
\hline $\operatorname{gram}(\mathrm{g})$ & 0.03527 & ounce, avoirdupois (oz) \\
\hline
\end{tabular}

Temperature in degrees Celsius $\left({ }^{\circ} \mathrm{C}\right)$ may be converted to degrees Fahrenheit $\left({ }^{\circ} \mathrm{F}\right)$ as follows:

$$
{ }^{\circ} \mathrm{F}=\left(1.8 \times{ }^{\circ} \mathrm{C}\right)+32 \text {. }
$$

\section{Abbreviations}

Campground Cowlitz Falls Campground on Cowlitz River Arm of Lake Scanewa

Cispus Arm Cispus River Arm of Lake Scanewa

Cowlitz Arm Day Use Park on Cowlitz River Arm of Lake Scanewa

GLM Generalized linear model

SD standard deviation

PUD Public Utility District 



\title{
Behavior and Survival of Hatchery Rainbow Trout (Oncorhynchus mykiss) in the Upper Cowlitz River Basin, Washington, 2013 and 2017
}

\author{
By Amy C. Hansen, Tobias J. Kock, Brian K. Ekstrom, and Theresa L. Liedtke
}

\section{Abstract}

A two-year study (2013 and 2017) was conducted to determine if annual releases of hatchery rainbow trout (resident Oncorhynchus mykiss) in the upper Cowlitz River Basin, Washington adversely affected anadromous fish in the basin. Rainbow trout tagged with radio transmitters were monitored after release to describe movement patterns, entrainment rates at Cowlitz Falls Dam, and survival. Additionally, trout that were radio-tagged in 2017 were monitored during spring 2018 to determine if any moved upstream and entered tributaries where winter steelhead (anadromous Oncorhynchus mykiss) spawning occurs. A total of 580 hatchery rainbow trout (122 in 2013 and 458 in 2017) were radio-tagged and released at three release sites: (1) Cowlitz Falls Campground on Cowlitz River Arm of Lake Scanewa river kilometer (rkm) 155, (2) Cispus River Arm of Lake Scanewa rkm 1, and (3) Day Use Park on Cowlitz River Arm of Lake Scanewa rkm 146. Most radio-tagged trout (70 percent) remained within $6.4 \mathrm{rkm}$ of the release site but some fish moved at least $25.7 \mathrm{rkm}$ from the release site. The predominant movement direction was downstream. More than twice as many fish released at Cowlitz Falls Campground in 2017 (compared to the other two release sites) remained in the Cowlitz River, where potential overlap with steelhead occurs. A total of 28.3 percent of the study fish were entrained at Cowlitz Falls Dam. Apparent survival (time until movement ceased) for most tagged trout was fewer than 100 days from release in both years and no fish were detected moving during the spring following their release. In summary, hatchery rainbow trout released upstream from Cowlitz Falls Dam seem to remain primarily in Lake Scanewa or entrained at Cowlitz Falls Dam with few fish surviving to winter months. We found no evidence of hatchery trout interacting with steelhead in spawning tributaries during spring months. These results suggest that trout stocking in the upper Cowlitz River Basin poses minimal threat to anadromous fish in the basin.

\section{Introduction}

Hatchery rainbow trout (Oncorhynchus mykiss) are commonly released into streams, lakes, and reservoirs to provide or supplement fisheries in various locations worldwide (MacCrimmon, 1971; Walters and others, 1997; Bettinger and Bettoli, 2002; Farrington and others, 2004; High and Meyer, 2009; Candiotto and others, 2011). In the Pacific Northwest, United States, rainbow trout are annually released in some rivers to mitigate for fisheries that were eliminated because of the construction and operation of hydropower dams. Dams and reservoirs blocked access to the habitat of native anadromous salmon, resulting in the extirpation of these fishes upstream from many dams. In some cases, mitigation fisheries have been established to offset these losses.

In Lake Scanewa, upstream from Cowlitz Falls Dam, approximately 25,000 rainbow trout are released each year during June-August to mitigate for lost fishing opportunities when dams were constructed in the Cowlitz River during the 1960s and 1990s. If many unharvested trout remain in the upper Cowlitz River Basin, resident and anadromous fishes could potentially be impacted. Estimates from creel surveys conducted during 2000 and 2010 indicated that less than onehalf of the released hatchery trout were eventually captured by anglers (Tipping and Serl, 2000; Liedtke and others, 2011). Liedtke and others (2011) also found 2.6 percent of trout greater than $(>) 30$ centimeters $(\mathrm{cm})$ and 0.2 percent of trout less than $(<) 30 \mathrm{~cm}$ had salmonids in their stomachs. Because the stomach content sampling did not seasonally coincide with the peak abundance of salmon fry and parr, these were likely conservative estimates of predation. These results indicated that hatchery trout could have an impact on juvenile salmonid populations, but dispersal and survival of the trout are unknown. Studies of hatchery rainbow trout in the upper Cowlitz River Basin prior to 2013 have focused on creel surveys and stomach samples to estimate impact on anadromous salmonids. 
A substantial amount of research has assessed how hatchery rainbow trout respond after release in recreational fisheries. In general, studies have shown that rainbow trout tend to have low return-to-creel rates, limited dispersal from release sites, and low survival. Research on return-to-creel rates suggests that less than 50 percent of the released trout are eventually harvested by anglers (Cresswell, 1981; Heimer and others, 1985; Wiley and others, 1993). Previous studies on the Cowlitz River are consistent with this finding, with return-to-creel of 37.9 percent (Liedtke and others, 2011) and 41 percent (Tipping and Serl, 2000). In many studies, hatchery rainbow trout generally remained close to the stocking site. Post-release dispersal in rivers and streams was often within 5 river kilometers (rkm) (Shetter, 1947; Bjornn and Mallet, 1964; Bettinger and Bettoli, 2002; High and Meyer, 2009), but most fish were caught within $1 \mathrm{rkm}$ of the stocking location (Trembley, 1945; Helfrich and Kendall, 1982; Heimer and others, 1985; Baird and others, 2006). However, some studies showed rainbow trout moved as far as $24 \mathrm{rkm}$ away (Shetter and Hazzard, 1941; Bjornn and Mallet, 1964; Bettinger and Bettoli, 2002). The limited dispersal of stocked fish is beneficial for anglers (if access is not limited) and may help reduce potential interactions with native populations.

Stocked hatchery rainbow trout can reduce native fish populations because of competition and predation (Miller, 1958; Beauchamp and others, 1995; Seiler and Keeley, 2009). Competition for resources such as space and food can contribute to low survival of resident fish, especially at high stocking rates (Petrosky and Bjornn, 1988). Hatchery fish tend to be more aggressive, more active, and are larger than wild conspecifics and therefore have a higher metabolic rate (Butler, 1975; Ersbak and Haase, 1983; Mesa, 1991; McMichael and others, 1999; Bettinger and Bettoli, 2002). Bachman (1984) found wild brown trout used a sit-and-wait approach for feeding, taking advantage of drifting food while hatchery fish moved more and fed less. The potential negative impacts that hatchery trout might have on resident populations would be short-term if the stocked fish died quickly or moved downstream. Research has shown that most rainbow trout survive less than 90 days following release (Shetter and Hazzard, 1941; Walters and others, 1997; Bettinger and Bettoli, 2002; High and Meyer, 2009) and few trout survive to the following fishing season after a winter (Shetter and Hazzard, 1941; Cooper, 1953; Heimer and others, 1985; Wiley and others, 1993; Meyer and Griffith, 1997).

We conducted a study in two separate years (2013 and 2017), using radio telemetry to quantify movement and survival of hatchery rainbow trout from three release sites in the upper Cowlitz River Basin. The objectives were to assess postrelease movement, post-release survival, and potential spatial overlap with spawning steelhead.

\section{Study Area}

The Cowlitz River, in southwestern Washington, is a primary tributary to the lower Columbia River, the largest river in the Pacific Northwest. The Cowlitz River drains 6,698 square kilometers $\left(\mathrm{km}^{2}\right)$ on the western slopes of the Cascade Mountain range. Three dams are present: Mayfield (rkm 84) and Mossyrock (rkm 105) dams, constructed during the 1960s, and Cowlitz Falls Dam (rkm 143), which began operating in 1994. The upper Cowlitz River Basin, located upstream from Cowlitz Falls Dam, is drained by the Cowlitz $\left(1,577 \mathrm{~km}^{2}\right.$ drainage area) and Cispus $\left(1,121 \mathrm{~km}^{2}\right.$ drainage area) rivers (fig. 1). They share a confluence at rkm 144, near the center of Lake Scanewa, a small reservoir which has a surface area of 264 hectares. Hatchery trout were stocked in three locations: (1) Cowlitz Falls Campground on Cowlitz River Arm of Lake Scanewa (Campground) at rkm 155, (2) Cispus River Arm of Lake Scanewa (Cispus Arm) at rkm 1, and (3) Day Use Park on Cowlitz River Arm of Lake Scanewa (Cowlitz Arm) at rkm 146. Radio-tagged fish were released at Campground, Cispus Arm and Cowlitz Arm (fig. 1). 


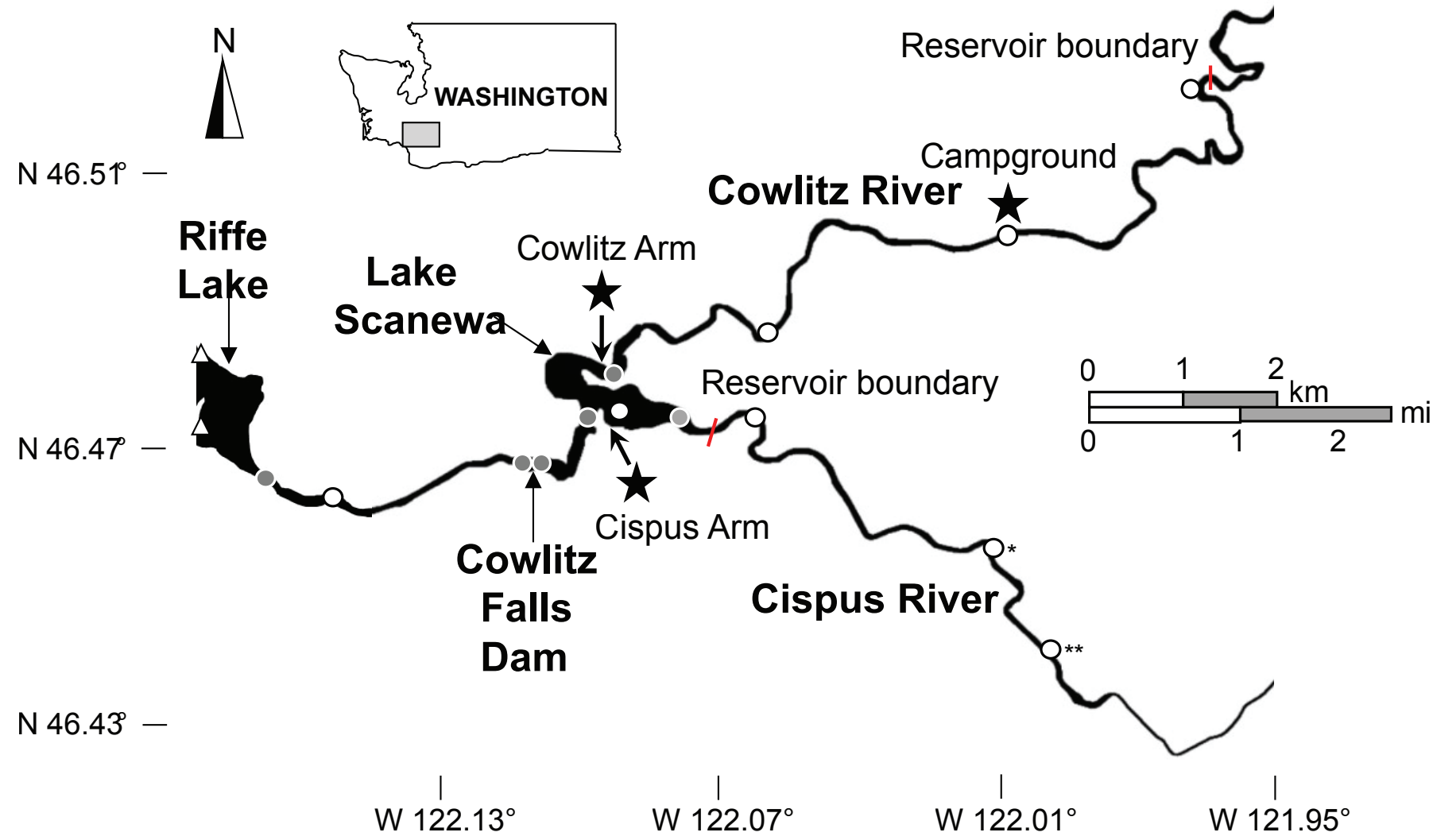

Figure 1. Locations of fixed radio telemetry monitoring sites used only in 2013 (open triangles), fixed radio telemetry sites used in 2013 and 2017 (filled circles), fixed radio telemetry sites used in 2017 (open circles), and locations where radio-tagged rainbow trout were released (large stars), upper Cowlitz River Basin, Washington. Boundaries between the reservoir Lake Scanewa and the riverine Cowlitz and Cispus Rivers are denoted by red lines perpendicular to the rivers. [*, site added August 2017; ${ }^{* *}$, site removed August 2017.]

\section{Methods}

\section{Radio Telemetry Monitoring}

Radio telemetry monitoring sites (hereafter, fixed sites) were installed at several locations in the Cowlitz River basin during 2013 and 2017 to monitor movements of rainbow trout that were tagged and released for the study. (fig. 1).

In 2013, fixed sites were installed at the following locations:

- Riffe Lake, Cowlitz River rkm 132.9

- Taidnapam Park, Cowlitz River rkm 136.8

- Cowlitz Falls Dam tailrace, Cowlitz River rkm 141.8

- Cowlitz Falls Dam Fish Facility, Cowlitz River rkm 142.1

- Cowlitz Falls Dam forebay, Lake Scanewa rkm 142.6

- PUD boat launch, Lake Scanewa rkm 144.0
- Day Use Park, Cowlitz River Arm of Lake Scanewa rkm 146.1

- Copper Creek, Cispus River Arm of Lake Scanewa rkm 1.6

In 2017, fixed sites were installed at the following locations:

- Taidnapam Park, Cowlitz River rkm 136.8

- Washington Department of Fish and Wildlife office, Cowlitz River rkm 138.4

- Cowlitz Falls Dam tailrace, Cowlitz River rkm 141.8

- Cowlitz Falls Dam Fish Facility, Cowlitz River rkm 142.1

- Cowlitz Falls Dam forebay, Lake Scanewa rkm 142.6

- Cowlitz Falls Dam fish separator, Lake Scanewa rkm 142.6 
- Mooring site, Lake Scanewa rkm 144.2

- Day Use Park site, Cowlitz River Arm of Lake Scanewa rkm 146.1

- Cowlitz River Arm of Lake Scanewa rkm 149.7

- Cowlitz Falls Campground, Cowlitz River Arm of Lake Scanewa rkm 154.5

- Lewis County PUD, Cowlitz River Arm of Lake Scanewa rkm 162.5

- Cispus Island, Cispus River Arm of Lake Scanewa rkm 0.6

- Copper Creek, Cispus River Arm of Lake Scanewa rkm 1.6

- 200 Road, Cispus River rkm 4.8

- Kritter Camp, Cispus River rkm 8.0, deployed August 2017

- 25 Road bridge, Cispus River rkm 11.3, removed August 2017

Mobile tracking was conducted (by vehicle and boat) to augment detections from fixed sites. During the 2013 study year, mobile tracking occurred on three dates: September 7, 2014; November 16, 2014; and January 25, 2015. In 2017, mobile tracking occurred on 14 dates during July-November, 2017. Trout tagged in 2013 were monitored on fixed gear through June 30, 2014, and trout tagged in 2017 were monitored on fixed gear until July 25, 2018. Trout mobile tracking was supplemented by a concurrent radio telemetry study monitoring adult steelhead in 2017 and 2018 in Lake Scanewa and the Cowlitz and Cispus Rivers, upstream from the trout monitoring fixed sites (Liedtke and others, 2020).

\section{Fish Tagging and Releasing}

On each stocking date, hatchery rainbow trout (hereafter, rainbow trout) were transported by truck from a commercial facility near Orting, Washington (about 1-hour transport time) to release locations in the upper Cowlitz River Basin. Approximately 25,000 fish, averaging 2 fish per pound, were stocked bi-monthly during June-August per year. Stocked fish were released at three sites on each release date (fig. 1).

Study fish were subsampled from the stocked fish just prior to release or collected in the reservoir. During the 2013 study, approximately 40 fish were radio-tagged in July, August, and November for a total of 122 trout (table 1). During the July and August tagging events, fish were netted from the transport truck at the Cispus Arm stocking site located at rkm 1. Following tagging at the Cispus Arm site, one-half of the fish were released, and one-half were transported by boat to the Cowlitz Arm and released. During the November tagging event, fish were collected in Lake Scanewa using hook and line, transported to the PUD boat launch for radio-tagging, and then transported by boat to the Cowlitz Arm and Cispus Arm release sites. In 2017, fish were netted from the transport truck, tagged, and released at three stocking sites - Campground, Cispus Arm, and Cowlitz Arm. Approximately 50 tagged rainbow trout were released at each stocking site in June, July, and August, for a total of approximately 150 fish each month (table 1).

Prior to tagging, fish were held in containers with flowthrough river water at densities less than 20 grams (g) of fish per liter of water. Collected fish were held from 1 to 6 hours until tagging, except for the fish collected by angling in November of 2013, which were held overnight to recover from collection then tagged and released the following day. Radio transmitters were surgically implanted using methods described by Liedtke and others (2012). Ten percent Aqui-S $20 \mathrm{E}^{\circledR}$ (Aqua Tactics, Kirkland, Washington) was used as an anesthetic during tagging. Radio-tag model TX-PSC-I-450 (8.5 g in air; Sigma Eight, Inc.) was implanted during 2013.

Table 1. Number and size of hatchery rainbow trout tagged and released, by month of release, in the upper Cowlitz River Basin, Washington, 2013 and 2017.

[N, sample size; min, minimum; max, maximum; St. dev., standard deviation]

\begin{tabular}{|c|c|c|c|c|c|c|c|}
\hline \multirow{2}{*}{ Month } & \multirow{2}{*}{$N$} & \multicolumn{3}{|c|}{ Fork length (centimeters) } & \multicolumn{3}{|c|}{ Weight (grams) } \\
\hline & & Mean (min-max) & Median & St. dev & Mean (min-max) & Median & St. dev. \\
\hline \multicolumn{8}{|c|}{2013} \\
\hline Jul & 40 & $26.0(24.2-28.2)$ & 25.8 & 1.1 & $200.9(168.9-265.5)$ & 195.6 & 24.1 \\
\hline Aug & 41 & $26.9(21.8-30.8)$ & 26.6 & 1.6 & $218.1(180.0-331.0)$ & 210.0 & 32.1 \\
\hline Nov & 41 & $27.3(25.3-30.0)$ & 27.4 & 1.1 & $210.6(172.3-280.6)$ & 206.8 & 25.8 \\
\hline \multicolumn{8}{|c|}{2017} \\
\hline Jun & 152 & $25.0(13.8-29.5)$ & 25.2 & 1.9 & $158.8(80.2-261.3)$ & 156.0 & 33.1 \\
\hline Jul & 150 & $25.6(21.0-30.2)$ & 25.7 & 1.5 & $176.4(103.1-252.7)$ & 174.7 & 31.0 \\
\hline Aug & 156 & $25.8(14.3-30.3)$ & 25.8 & 1.8 & $181.4(118.0-313.1)$ & 178.1 & 34.2 \\
\hline
\end{tabular}


In 2017, model TX-PSC-I-80 (4.2 g in air; Sigma Eight, Inc.) was used to accommodate smaller fish. Expected life of the transmitters was 2,501 days in 2013 and 445 days in 2017. Tagged fish recovered for 10 minutes or until fish reached equilibrium in 68-liter plastic totes and then were released.

There were no differences in fish size between release sites, but size varied by month (fig. 2; table 1). In 2013, there were no differences in mean fork length or weight of fish between release sites (one-way generalized linear model [GLM]; fork length $P=0.9754$; weight $P=0.3430$ ). Fork lengths of tagged fish ranged from 21.8 to $30.8 \mathrm{~cm}$ (mean 26.7; standard deviation [SD] 1.4) and weights ranged from 168.9 to $331.0 \mathrm{~g}$ (mean 210.0; SD 28.3). Fork length increased each month (one-way GLM; $P<0.0001$ ) and fish were heavier in August than the other two months (one-way GLM; $P=0.0219$; fig. 2; table 1), but lighter in November. In 2017, there were no differences in mean fork length or weight of fish between release sites (one-way GLM; fork length $P=0.2119$; weight $P=0.0822$ ). Fish were longer and heavier in each consecutive tagging event (one-way GLM; $P=0.0002$;
$P=0.0001)$. Mean fish size in 2017 was $25.5 \mathrm{~cm}$ fork length (range 13.8-30.3; SD 1.8) and a weight of $172.4 \mathrm{~g}$ (range 80.2-313.1; SD 34.2; fig. 2; table 1). Mean tag burden (weight of the transmitter expressed as a percentage of fish weight) was 4.1 percent in 2013 and 2.5 percent in 2017.

\section{Data Analysis}

Detection records from fixed telemetry sites and from mobile tracking were merged with tagging and release data to create a combined detection dataset. False positive detections were identified in the dataset using an automated filter described in Beeman and Perry (2012). The remaining data were reviewed by the authors and reconciled to create the final dataset. All Global Positioning System coordinates of fish locations were rounded to the nearest river mile in each river or creek and then converted to river kilometers. These data were managed, processed, and analyzed using $\mathrm{SAS}^{\circledR}$ version 9.4 (Cary, North Carolina).

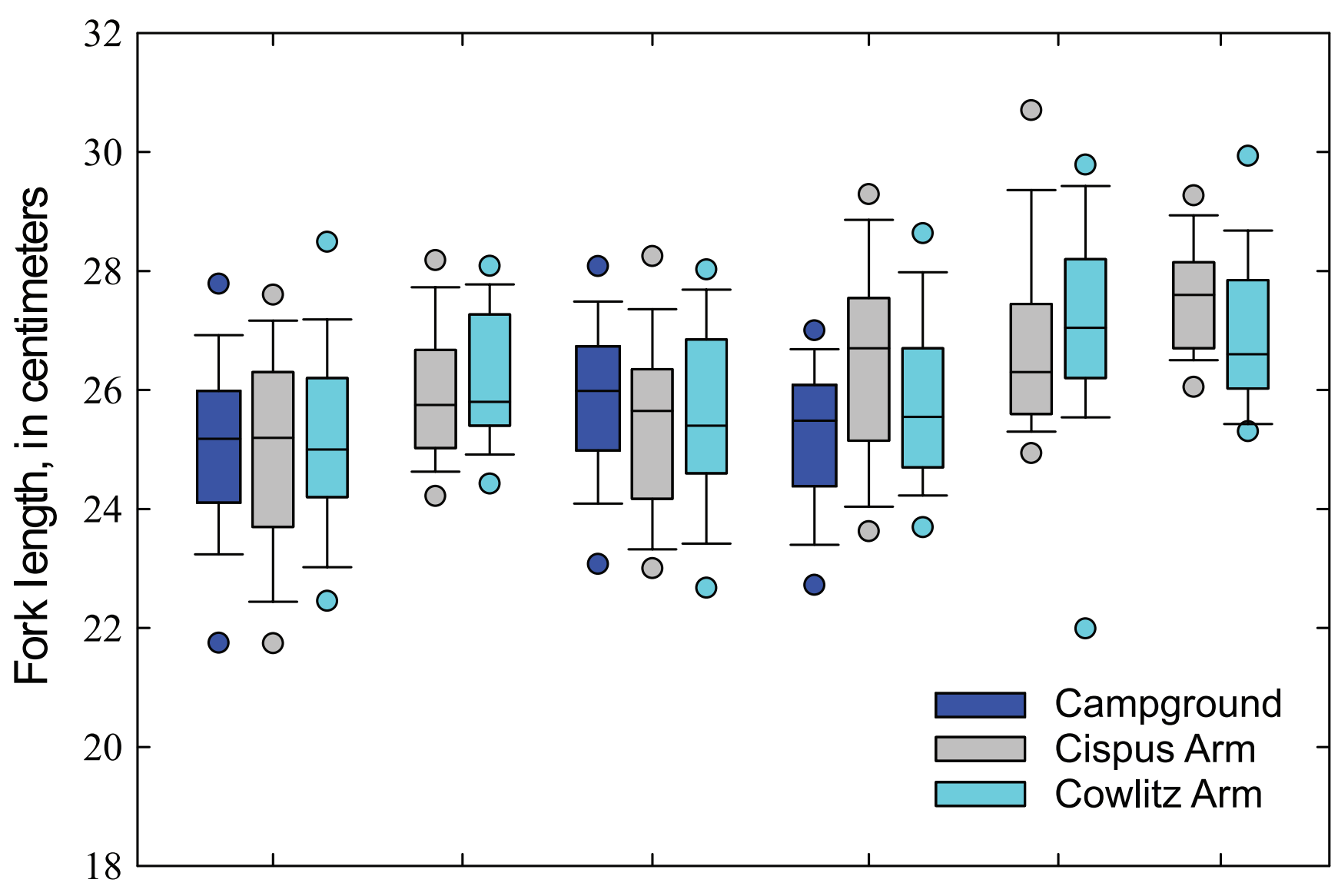

June 20, 2017 July 2, 2013 July 25, 2017

Aug. 8, 2017 Aug. 13, 2013 Nov. 5, 2013

\section{Release dates}

Figure 2. Radio-tagged hatchery rainbow trout fork lengths by date and release location in the upper Cowlitz River Basin, Washington, 2013 and 2017. Box hinges are the 25th and 75th percentiles, the line bisecting the box is the median, whiskers are the 10th and 90th percentiles, and dots are the 5th and the 95th percentiles. 
Our goal was to determine the following: (1) how far fish moved away from release sites, (2) how long fish survived after release, (3) the proportion of released fish that were entrained at Cowlitz Falls Dam, and (4) if tagged rainbow trout were detected in steelhead spawning tributaries during the steelhead spawning period. The maximum distance moved was calculated to determine the maximum river kilometer detected upstream and downstream from each release site. Fish entrained at the dam were of interest because they were no longer available for harvest. Entrainment at Cowlitz Falls Dam occurred if a fish passed downstream from the dam through the turbines or into the fish collection facility. Percent entrainment was calculated by dividing the number of tagged fish collected at Cowlitz Falls Dam or detected downstream from Cowlitz Falls Dam by the total number of tagged fish released during each study year. To determine if a flow-entrainment relationship existed, mean daily flow data on the Cowlitz River downstream from Cowlitz Falls Dam were downloaded from U.S. Geological Survey National Water Information System (U.S. Geological Survey, 2020) and compared to daily observations of tagged fish in the collection facility at the dam and downstream from the dam. Apparent survival was calculated using fish movement data. Fish detected moving within the study area were assumed to be alive, whereas fish that stopped moving and never were detected moving again were assumed to be dead. Apparent survival was defined as the elapsed time from release until movement cessation. Elapsed time from release to movement cessation was plotted using the Kaplan-Meier survivorship function to illustrate apparent survival. Statistical significance was assessed using an alpha of 0.05 when comparing apparent survival.

The fate of each fish was identified to estimate the percentage of fish that were in the Cowlitz River or Cispus River, that remained in Lake Scanewa, fell back downstream from Cowlitz Falls Dam, or were harvested or predated. Fish were assigned Cowlitz River or Cispus River fates if they were last detected in either river; fish were assigned a Lake Scanewa fate if they were last detected in Lake Scanewa; and fish were assigned an entrainment fate if they were detected downstream from Cowlitz Falls Dam or collected in the fish collection facility at the dam. Harvest was determined from angler reports. In addition, tags mobile tracked to residences were assigned to the harvest fate. Fish that were tracked to areas on land or near birds of prey nesting areas were assigned to a predation fate.

\section{Evaluation of Spawning Overlap with Steelhead}

During 2017 and 2018, a concurrent telemetry study was conducted in the upper Cowlitz River Basin that focused on adult steelhead (O. mykiss) movements (Liedtke and others, 2020). A total of 130 natural and 85 hatchery-origin steelhead were radio-tagged and released at the Cowlitz Arm site and at rkm 28 in the Cispus River from February through May of 2017 and 2018. From March 2017 to July 2018, we mobile tracked radio-tagged steelhead and trout in an area encompassing the trout study $-45 \mathrm{rkm}$ in the Cispus River near the confluence of Prospect Creek and the $72 \mathrm{rkm}$ in the Cowlitz River upstream from Cowlitz Falls Dam. Nearby tributaries were also monitored; mobile tracking occurred in 18 Cowlitz River tributaries and 13 Cispus River tributaries.

\section{Results}

A total of 69.6 percent of tagged fish stayed within 6.4 rkm of the release site but some fish moved at least $25.7 \mathrm{rkm}$ from the release site (fig. 3). A total of 24.7 percent of fish moved between 6.5 and $12.9 \mathrm{rkm}$ while few fish (5.5 percent) moved more than $12.9 \mathrm{rkm}$ away from the release site (fig. 3). Five percent of fish did not leave the release site and, of the fish that did move from the release site, movement was limited and predominantly downstream. The median maximum distance moved was $3.2 \mathrm{rkm}$ downstream and $0 \mathrm{rkm}$ upstream for both years. Tagged fish moved greater distances away from the release site in 2017 than in 2013 and were detected as far as $25.7 \mathrm{rkm}$ upstream and $24.1 \mathrm{rkm}$ downstream. There were few differences in maximum distance moved between release month in either year, but some fish in 2017 moved a greater distance upstream after release in July and August than in June.

Most fish released at the Lake Scanewa release sites (Cispus and Cowlitz Arms) stayed in Lake Scanewa or were entrained (were collected at or passed through Cowlitz Falls Dam in Lake Scanewa). Similarly, most (67.3 percent) of the fish released at the river site (Campground) remained in the Cowlitz River. More than one-half (58.2 percent) of the 2013 trout and 30.8 percent of the 2017 trout released at Cispus or Cowlitz Arms had fates indicating their last detection was in Lake Scanewa compared to 0.7 percent of the Campgroundreleased fish (table 2). In 2013, few fish had river fates (Cowlitz or Cispus) while 3.3, 6.5, 15.7, and 20.4 percent of fish released at the Lake Scanewa release sites had river fates in 2017 (table 2). River fates suggest a potential overlap with steelhead who spawn in the upstream tributaries of the Cowlitz and Cispus Rivers and 67.3 percent of Campground fish remained in the Cowlitz River at the end of the study. 


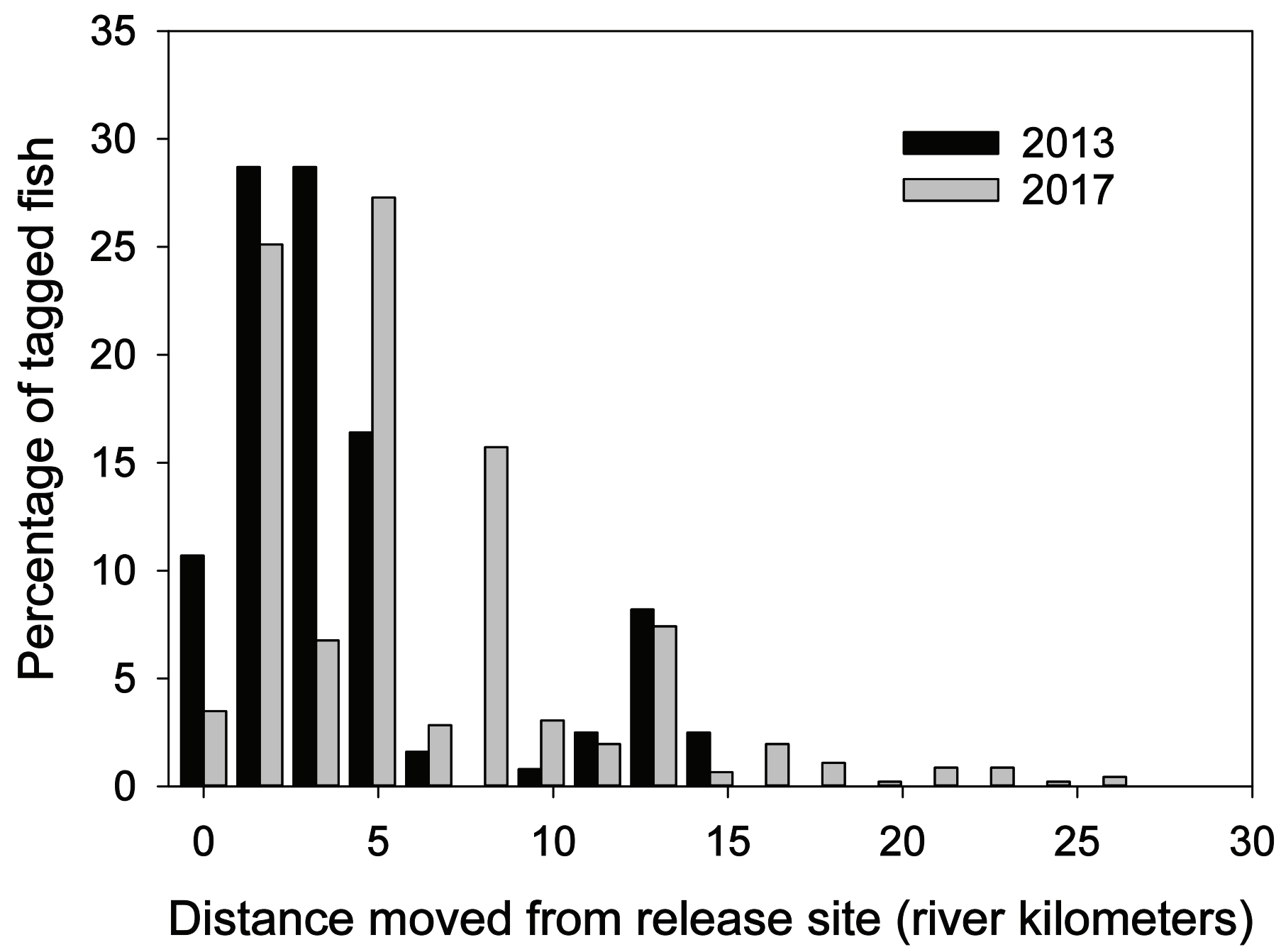

Figure 3. Percentage of radio-tagged rainbow trout by maximum distance moved from release site in the upper Cowlitz River Basin, Washington, 2013 and 2017.

Table 2. Percentage of fish and their fate, by year of release, in the upper Cowlitz River Basin, Washington, 2013 and 2017.

[Campground, Cowlitz Falls Campground on Cowlitz River Arm of Lake Scanewa]

\begin{tabular}{lccccccr}
\hline \multicolumn{1}{c}{ Release site } & No detections & Cowlitz River & Cispus River & Lake Scanewa & Entrained & Harvest & Predation \\
\hline & \multicolumn{7}{c}{2013} \\
Cispus Arm & 1.6 & 1.6 & 0.0 & 66.1 & 22.6 & 1.6 & 6.5 \\
Cowlitz Arm & 0.0 & 13.3 & 0.0 & 50.0 & 21.7 & 5.0 & 10.0 \\
Total 2013 & 0.8 & 7.4 & 0.0 & 58.2 & 22.1 & 3.3 & 8.2 \\
\hline & & 2017 & & & & \\
\hline Campground & 0.0 & 67.3 & 0.7 & 0.7 & 22.9 & 5.9 & 2.6 \\
Cispus Arm & 1.3 & 6.5 & 15.7 & 38.6 & 26.1 & 1.3 & 10.5 \\
Cowlitz Arm & 0.7 & 20.4 & 3.3 & 23.0 & 40.8 & 3.9 & 7.9 \\
Total 2017 & 0.7 & 31.4 & 6.6 & 20.7 & 29.9 & 3.7 & 7.0 \\
\hline
\end{tabular}


Few tagged fish were reported as harvested in either year. Of the 122 radio-tagged trout released in 2013 , four ( 3.3 percent) were known to be harvested, three of them between December 2013 and January 2014. Harvests occurred 22, 25,61 , and 86 days after release. In 2017, four tags were reported as harvested fish by anglers. These fish were released at the Cispus Arm $(n=2)$ and Cowlitz Arm $(n=2)$ sites. Of the reported harvest, fish were captured 14, 32, 32, and 52 days after release. Several radio tags were mobile tracked to areas considered to be evidence of harvest, such as near a residence. An additional 13 fish in 2017 were considered harvested for a total of 3.3 percent in 2013 and 3.7 percent in 2017 (table 2). Total harvest numbers are likely underestimated due to few reported harvested fish compared to other studies in the upper Cowlitz River Basin. Some fish were mobile tracked to locations indicating predation, including proximity to a bird of prey nest. Ten fish in 2013 (8.2 percent) and 32 fish in 2017 ( 7.0 percent) were assigned predation as their final fate (table 2).

A total of 28.3 percent of fish released were entrained at Cowlitz Falls Dam by either collection at the Cowlitz Falls Fish Facility or fallback downstream into Riffe Lake. A nearly equal percentage of fish released in 2013 at the two release sites were detected as fallbacks in Riffe Lake (22.6 and 21.7 percent; table 2). No radio-tagged trout were recorded at the collection facility in 2013. In 2017, 7.6 percent of fish were collected at Cowlitz Falls Dam and 22.3 percent were detected as fallbacks in Riffe Lake. Fish released at the Cowlitz Arm site experienced substantially higher fallback than fish released at the Cispus Arm and Campground sites (table 2). Most entrainment occurred in August and early September when flows were low, but entrainment continued throughout winter in both years (fig. 4). Median time to entrainment was 33.5 days in 2013 and 9.4 days in 2017.

Most fish were entrained or stopped moving and were assumed to have died within 100 days of release. Median apparent survival (time from release to entrainment or movement cessation) was nearly double in 2013 (30.4 days) than in 2017 (16.4 days) but the survival trends were similar (fig. 5). A total of 75 percent of fish stopped moving by day 57 in 2013 and day 45 in 2017 and less than 9.0 percent of fish were detected moving within the study area after 100 days in both years. None of the tagged trout were detected moving during spring months in the year following release. There were no differences in apparent survival between month of release in either year (Wilcoxon test, 2013: $Z=4.3145, P=0.1156$; 2017 : $Z=3.7221, P=0.1555)$. In 2017, fish released at the Cispus Arm had slightly longer apparent survival (median Cispus Arm 26.2 days) compared to fish released at the other two sites (median Campground 13.7 days; Cowlitz Arm 12.8 days).

\section{Evaluation of Spawning Overlap with Steelhead}

The last detected movement of any rainbow trout was within 165 days of release and no movement was detected the following spring of either year. Some radio-tagged trout moved upstream and were last detected in the Cowlitz and Cispus Rivers during the year they were released. However, all those fish had detection histories which indicated that they died, and we never detected tagged rainbow trout in either river the following spring when steelhead spawning occurred. No tagged trout were detected during mobile tracking as part of the steelhead effort in 2018. No radio-tagged trout released in 2013 or 2017 were found in steelhead spawning tributaries. 


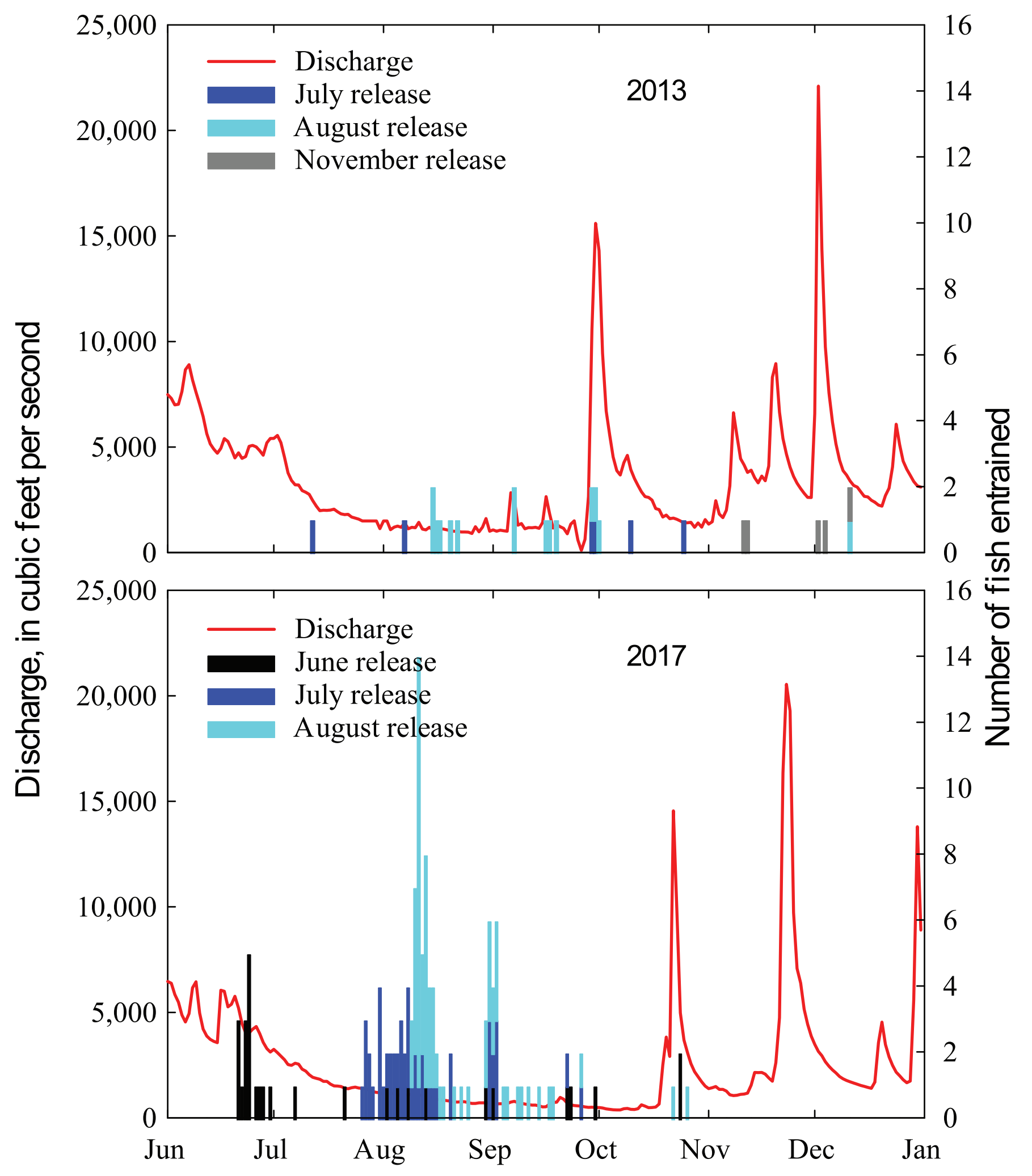

Figure 4. Number of radio-tagged rainbow trout, by date and release month, entrained at the Cowlitz Falls Dam and line graph showing discharge at Cowlitz Falls Dam in the upper Cowlitz River Basin, Washington, 2013 and 2017. 


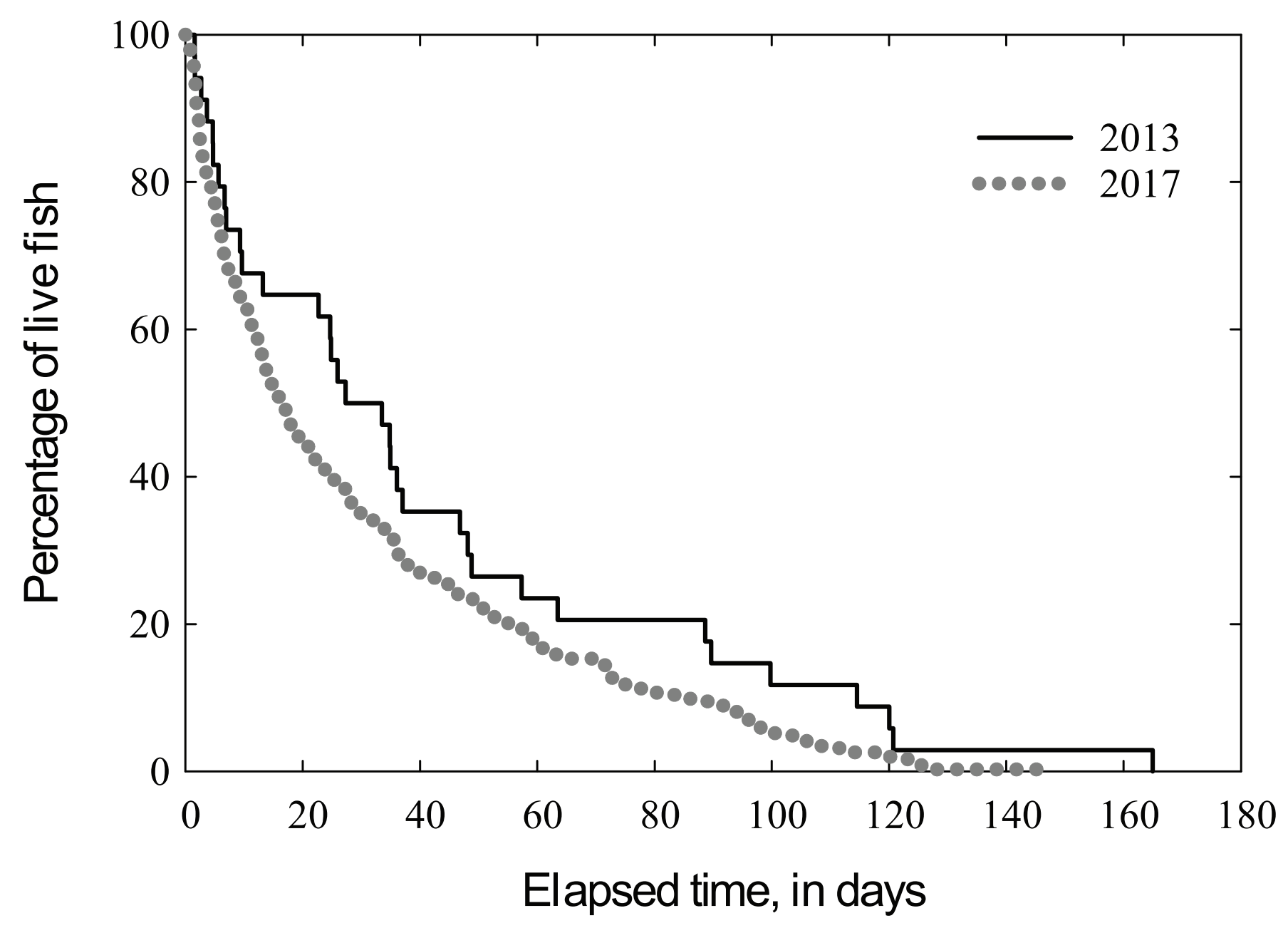

Figure 5. Apparent survival of radio-tagged rainbow trout, in days by year of release, in the upper Cowlitz River Basin, Washington, 2013 and 2017.

\section{Discussion}

Tagged hatchery rainbow trout primarily remained near release sites and most had an apparent survival of less than 100 days. The results from this study are consistent with other studies. For example, Trembley (1945) and Baird and others (2006) found rainbow trout moved less than $1.6 \mathrm{rkm}$ from release locations in Spring Creek, Pennsylvania and the Moose River, New York, respectively. In other studies, rainbow trout moved less than $5 \mathrm{rkm}$ (Shetter, 1947; Bjornn and Mallet, 1964; High and Meyer, 2009). High and Meyer (2009) reported 85 percent of trout were presumed dead at 30 days after release in an Idaho River. In Tennessee, 93 percent of stocked rainbow trout died or moved out of the study area within 11 weeks of stocking (Bettinger and Bettoli, 2002).

Similarly, in the Colorado River, trout were only caught within four weeks of stocking (Walters and others, 1997). Our findings suggest that rainbow trout survival in the upper Cowlitz
River Basin is relatively short, providing angling opportunities in the summer months near the release sites, but long-term survival beyond the summer fishing season is limited.

High harvest rates close to the stocking dates can influence potential low survival within a few months after stocking (Cresswell, 1981; Dillon and others, 2000; High and Meyer, 2009). There were few reports of study fish harvested in either year of our study, which could be a result of our limited presence at the boat ramps during fishing season, lack of creel surveys, unreported or illegal harvest, or reluctance of anglers to report tags. From creel surveys in 2010, Liedtke and others (2011) reported 1,214 anglers resided in the county encompassing the study area. Using mobile tracking, we detected several unreported radio tags in residences, providing evidence to categorize these fish as harvested. These residences were away from water bodies, reducing the possibility of errant radio signals. In addition, we mobile tracked some transmitters to areas on land. These land-based locations could have been a combination of avian predation, natural mortality of a trout followed by scavengers dragging the carcass to land, or angler harvest and tag removal. More than one-half of the known 
harvest was within 32 days of release with the remaining harvest at 2-3 months from release. When combining reported harvest with predation from our mobile tracking efforts, our harvest rates are still likely underestimated. We found 11.5 and 10.7 percent combined harvest and predation in our 2013 and 2017 study years, respectively. Creel surveys were not conducted in either study year. Using creel surveys, Tipping and Serl (2000) and Liedtke and others (2011) reported 38-41 percent of stocked rainbow trout were harvested in the upper Cowlitz River Basin, leaving many fish in our studies unaccounted for.

Once released, hatchery fish have a hard time transitioning from manufactured pellets to variable and seasonal food sources in the wild. In the wild, hatchery fish concentrate on food that is similar in size, shape, and coloration to artificial food pellets in hatchery diets (Ersbak and Haase, 1983). In the first months after stocking, planted hatchery trout lost weight due to starvation (Miller, 1952; Ersbak and Haase, 1983). As food resources change throughout the year, hatchery rainbow trout had difficulty adapting to available food as evidenced by few prey items (Fenner and others, 2004) and limited variety in their diet (Weiland and Hayward, 1997). In addition to limited variety in their diet, hatchery trout tended to spend more time and effort actively feeding, thereby increasing their caloric requirements (Butler, 1975; Bachman, 1984). Although it was not a formal part of our study, we observed evidence of the feeding challenges for hatchery rainbow trout. Fish collected for tagging by angling in the upper Cowlitz River Basin in November 2013 were the survivors of the July and August releases. The fish collected in November had greater fork length but weighed less than those released in July and August, suggesting that trout released in the upper Cowlitz River Basin lost weight in the 3-4 months following release. Water temperature, food availability, and competition can affect growth rates (Miller, 1958; Beauchamp and others, 1995; Baird and others, 2006; Seiler and Keeley, 2009), but based on examination of stomach contents (Liedtke and others, 2011), hatchery trout in this study seemed to not be feeding effectively. We believe this ineffective foraging was the primary factor influencing lack of growth. The lack of adapting to effectively foraging in the wild may cause some of the low apparent survival beyond 100 days.

Several studies have reported that hatchery rainbow trout consumed live prey. In laboratory trials, hatchery rainbow trout diets consisted of less than one-half of the prey than that of wild fish (Ward and others, 2018), suggesting that stocked trout may impact live prey less than native steelhead. In the upper Cowlitz River Basin, Liedtke and others (2011) found fish prey in 2.3 percent of stomachs sampled, but two-thirds of the prey were non-salmon species. Liedtke and others (2011) estimated their 2.1 percent of salmonid predation was an underestimate due to the timing of their creel census which coincided with fewer juvenile salmonids present. Predation was highest in the upper Cowlitz River Basin during February, March, and May (Liedtke and others, 2011), when few of the tagged trout were thought to be alive. Size of the fish can impact piscivory where larger fish consume more prey. Beauchamp (1990) reported rainbow trout $>25 \mathrm{~cm}$ were piscivorous throughout the year in Lake Washington, Washington. In the upper Cowlitz River Basin, more than eightfold of salmonids were consumed by trout $>30 \mathrm{~cm}$ long than trout less than $30 \mathrm{~cm}$ long (Tipping and Serl, 2000; Liedtke and others, 2011). Less than 1 percent of hatchery trout released in 2013 and 2017 were $>30 \mathrm{~cm}$, indicating that a small percentage of the stocked trout could be impacting live prey and juvenile salmonids could be at risk. However, few juvenile anadromous salmonids should be in the upper Cowlitz River Basin when trout are present, due to the short-term presence of most trout.

Our trout telemetry results indicated that few hatchery trout survive more than 3 months after release, and mobile tracking during the steelhead spawning period later in the year also failed to identify the presence of tagged trout in steelhead spawning tributaries. These findings align with one of the assumptions of the trout stocking program: that unharvested fish will not interact with natural-origin steelhead (Mike Kohn, Lewis County Public Utility District, personal communication, 2016). However, in other basins, resident rainbow trout have been shown to spawn with steelhead. In the Yakima River Basin in Washington, 7-20 percent of steelhead had resident maternal life histories in two separate years (Courter and others, 2013). McMillan and others (2007) reported mating attempts between female steelhead and wild resident males in the Calawah and Sol Duc river basins, Washington. In the Babine River in British Columbia, Canada, Zimmerman and Reeves (2000) reported mixing of maternal genes between rainbow trout and steelhead life histories. Of concern is the evidence that indicates hatchery fish may negatively impact wild fish through competition (physical contact, displacement; McMichael and others, 1999). Hatchery trout do interact with anadromous steelhead, although there is little evidence of it occurring in the upper Cowlitz River Basin based on our evaluations with tagged trout. However, in 2017 we captured video of a natural-origin male rainbow trout courting a radio-tagged female hatchery-origin steelhead in a tributary of the Cowlitz River (https://www.usgs.gov/media/videos/anadromoussteelhead-and-resident-rainbow-trout-interactions), illustrating the potential for steelhead-rainbow trout progeny.

Managers can improve the trout stocking program in the Cowlitz River Basin in several ways. They can continue to use several small releases of fish compared to one large one, allowing multiple periods when fish are available for harvest. Most of the angling is from June to September (Liedtke and others, 2011) and releases in these months will support angling opportunities. Fish released at the Cispus Arm site tend to remain near the release site for a longer period, allowing for greater opportunities of harvest. The falls just upstream from the Cispus Arm site may provide a partial natural barrier for rainbow trout because low numbers of tagged trout were detected upstream. Fish, including steelhead, can ascend the falls, but few trout do, keeping the trout mostly in the lake or the arms where they are less likely to interact with steelhead. 
While the Cowlitz Arm is convenient for anglers due to the proximity of a boat ramp, more fish released there are prone to entrainment at Cowlitz Falls Dam, making them unavailable for harvest. The risk of entrainment, although reducing angling opportunities, also reduces the risk of trout competing with anadromous fish in the upper Cowlitz River Basin. Entrainment is related to flows and lake drawdowns and is variable between years. Tagged fish moved a greater distance upstream after release in July and August than June 2017, likely seeking cooler water as Lake Scanewa warmed during the summer. Trout released at the Campground are more likely to head upstream or stay in the Cowlitz River, potentially interacting with steelhead. Eliminating the Campground release site, thereby reducing the total number of trout released, and continuing stocking trout at the lake release sites (Cispus and Cowlitz Arms) over a period of several months in the summer may be a strategy to provide continued angler satisfaction and minimize the likelihood of interactions with anadromous salmonid stocks.

In summary, the short apparent survival and limited movement of radio-tagged rainbow trout indicate stocked rainbow trout have a low impact to anadromous steelhead, either during spawning periods or during the juvenile outmigration when predation is a concern. However, not all the release locations posed equivalent risk to impacting anadromous fish. Eliminating the Campground release site may reduce the risk of potential interaction of rainbow trout and adult steelhead in the Cowlitz River and still assist in meeting the goals of the trout release program.

\section{References Cited}

Bachman, R.A., 1984, Foraging behavior of free-ranging wild and hatchery brown trout in a stream: Transactions of the American Fisheries Society, v. 113, no. 1, p. 1-32, accessed May 13, 2020, at https://doi.org/10.1577/15488659(1984)113<1:FBOFWA>2.0.CO;2.

Baird, O.E., Krueger, C.C., and Josephson, D.C., 2006, Growth, movement, and catch of brook, rainbow, and brown trout after stocking into a large, marginally suitable Adirondack River: North American Journal of Fisheries Management, v. 26, no. 1, p. 180-189, accessed May 13, 2020, at https://doi.org/10.1577/M04-183.1.

Beauchamp, D.A., 1990, Seasonal and diel food habits of rainbow trout stocked as juveniles in Lake Washington: Transactions of the American Fisheries Society, v. 119 , no. 3, p. 475-482, accessed August 25, 2020, at https://doi.org/10.1577/1548-8659(1990)119<0475:SADFH $\mathrm{O}>2.3 . \mathrm{CO} ; 2$.
Beauchamp, D.A., LaRiviere, M.G., and Thomas, G.L., 1995, Evaluation of competition and predation as limits to juvenile kokanee and sockeye salmon production in Lake Ozette, Washington: North American Journal of Fisheries Management, v. 15, no. 1, p. 193-207, accessed October 14, 2020, at https://doi.org/10.1577/1548-8675(1995)015<0193 :EOCAPA>2.3.CO;2.

Beeman, J.W., and Perry, R.W., 2012, Bias from false-positive detections and strategies for their removal in studies using telemetry, in Adams, N.S., Beeman, J.W., and Eiler, J.H., eds., Telemetry techniques-A user guide for fisheries research: Bethesda, Maryland, American Fisheries Society, p. 505-518.

Bettinger, J.M., and Bettoli, P.W., 2002, Fate, dispersal, and persistence of recently stocked and resident rainbow trout in a Tennessee tailwater: North American Journal of Fisheries Management, v. 22, no. 2, p. 425-432, accessed May 13, 2020, at https://doi.org/10.1577/1548-8675(2002)022<0425 :FDAPOR $>2.0 . \mathrm{CO} ; 2$.

Bjornn, T.C., and Mallet, J., 1964, Movements of planted and wild trout in an Idaho river system: Transactions of the American Fisheries Society, v. 93, no. 1, p. 70-76, accessed May 14, 2020, at https://doi.org/10.1577/1548-8659(1964) 93[70:MOPAWT]2.0.CO;2.

Butler, R.L., 1975, Some thoughts on the effects of stocking hatchery trout on wild trout populations, in King, W., Amato, F., Richardson, F., Bakke, B.M., eds., Proceedings of the Wild Trout Management Symposium, September 25-26, 1974: The Wild Trout Management Symposium, Yellowstone National Park, Wyoming, p. 83-87.

Candiotto, A., Bo, T., and Fenoglio, S., 2011, Biological and ecological data on an established rainbow trout (Oncorhynchus mykiss) population in an Italian stream: Fundamental and Applied Limnology, v. 179, no. 1, p. 67-76, accessed May 29, 2020, at https://doi.org/10.1127/ 1863-9135/2011/0179-0067.

Cooper, E., 1953, Returns from plantings of legal-sized brook, brown and rainbow trout in the Pigeon River, Otsego County, Michigan: Transactions of the American Fisheries Society, v. 82, no. 1, p. 265-280, accessed May 27, 2020, at https://doi.org/10.1577/1548-8659(1952)82[265:RFPO LB]2.0.CO;2.

Courter, I.I., Child, D.B., Hobbs, J.A., Garrison, T.M., Glessner, J.J.G., and Duery, S., 2013, Resident rainbow trout produce anadromous offspring in a large interior watershed: Canadian Journal of Fisheries and Aquatic Sciences, v. 70, no. 5, p. 701-710, accessed October 16, 2020, at https://doi.org/10.1139/cjfas-2012-0457. 
Cresswell, R.C., 1981, Post-stocking movements and recapture of hatchery-reared trout released into flowing waters-A review: Journal of Fish Biology, v. 18, no. 4, p. 429-442, accessed May 13, 2020, at https://doi.org/10.1111/j.10958649.1981.tb03784.x.

Dillon, J.C., Schill, D.J., and Teuscher, D.M., 2000, Relative return to creel of triploid and diploid rainbow trout stocked in eighteen Idaho streams: North American Journal of Fisheries Management, v. 20, no. 1, p. 1-9, accessed May 14, 2020, at https://doi.org/10.1577/1548-8675(2000)020<0 001:RRTCOT>2.0.CO;2.

Ersbak, K., and Haase, B.L., 1983, Nutritional depravation after stocking as a possible mechanism leading to mortality in stream-stocked brook trout: North American Journal of Fisheries Management, v. 3, no. 2, p. 142-151, accessed May 13, 2020, at https://doi.org/10.1577/1548-8659(1983)3 $<142$ :NDASAA $>2.0$.CO;2.

Farrington, L.W., Austin, C.M., Burridge, C.P., Gooley, G.J., Ingram, G.J., and Talbot, B., 2004, Allozyme diversity in Australian rainbow trout, Oncorhynchus mykiss: Fisheries Management and Ecology, v. 11, no. 2, p. 97-106, accessed August 25, 2020, at https://doi.org/10.1046/j.13652400.2003.00378.x.

Fenner, D.B., Walsh, M.G., and Winkelman, D.L., 2004, Diet overlap of introduced rainbow trout and three native fishes in an Ozark stream: American Fisheries Society Symposium, v. 44, p. 475-482.

Heimer, J.T., Frazier, W.M., and Griffith, J.S., 1985, Poststocking performance of catchable-size hatchery rainbow trout with and without pectoral fins: North American Journal of Fisheries Management, v. 5, no. 1, p. 21-25, accessed May 13, 2020, at https://doi.org/10.1577/15488659(1985)5<21:PPOCHR>2.0.CO;2.

Helfrich, L.A., and Kendall, W.T., 1982, Movements of hatchery-reared rainbow, brook, and brown trout stocked in a Virginia mountain stream: Progressive FishCulturist, v. 44, no. 1, p. 3-7, accessed May 14, 2020, at https://doi.org/10.1577/1548-8659(1982)44[3:MOHR BA]2.0.CO;2.

High, B., and Meyer, K.A., 2009, Survival and dispersal of hatchery triploid rainbow trout in an Idaho River: North American Journal of Fisheries Management, v. 29, no. 6, p. 1797-1805, accessed May 14, 2020, at https://doi.org/ 10.1577/M07-220.1.
Liedtke, T.L., Kock, T.J., Ekstrom, B.K., Tomka, R.G., and Rondorf, D.W., 2011, Evaluation of angler effort and harvest of rainbow trout (Oncorhynchus mykiss), Lake Scanewa, Washington, 2010: U.S. Geological Survey OpenFile Report 2011-1178, 24 p., accessed May 13, 2020, at https://doi.org/10.3133/ofr20111178.

Liedtke, T.L., Beeman, J.W., and Gee, L.P., 2012, A standard operating procedure for the surgical implantation of transmitters in juvenile salmonids: U. S. Geological Survey Open-File Report 2012-1267, 50 p., accessed May 13, 2020, at https:/pubs.usgs.gov/of/2012/1267/.

Liedtke, T.L., Kock, T.J., Hansen, A.C., Ekstrom, B.K., and Tomka, R.G., 2020, Behavior and movement of adult winter steelhead (Oncorhynchus mykiss) in the upper Cowlitz River Basin, Washington, 2017-18: U.S. Geological Survey Open-File Report 2020-1054, 35 p., accessed May 13, 2020, at http://doi.org/10.3133/ofr20201054.

MacCrimmon, H.R., 1971, World distribution of rainbow trout (Salmo gairdneri): Journal of the Fisheries Research Board of Canada, v. 28, no. 5, p. 663-704, accessed August 25, 2020, at https://doi.org/10.1139/f71-098.

McMichael, G.A., Pearsons, T.N., and Leider, S.A., 1999, Behavioral interactions among hatchery-reared steelhead smolts and wild Oncorhynchus mykiss in natural streams: North American Journal of Fisheries Management, v. 19, no. 4, p. 948-956, accessed May 15, 2020. 10.1577/1548-8675(1999)019<0948:BIAHRS>2.0.CO;2.

McMillan, J.R., Katz, S.L., and Pess, G.R., 2007, Observational evidence of spatial and temporal structure in a sympatric anadromous (winter steelhead) and resident rainbow trout mating system on the Olympic Peninsula, Washington: Transactions of the American Fisheries Society, v. 136, no. 3, p. 736-748, accessed October 16, 2020, at https://doi.org/10.1577/T06-016.1.

Mesa, M.G., 1991, Variation in feeding, aggression, and position choice between hatchery and wild cutthroat trout in an artificial stream: Transactions of the American Fisheries Society, v. 120, no. 6, p. 723-727, accessed May 13, 2020, at https://doi.org/10.1577/1548-8659(1991)120<0723:VIFA $\mathrm{AP}>2.3 . \mathrm{CO} ; 2$.

Meyer, K.A., and Griffith, J.S., 1997, First-winter survival of rainbow trout and brook trout in the Henrys Fork of the Snake River, Idaho: Canadian Journal of Zoology, v. 75, no. 1, p. 59-63, accessed June 3, 2020, at https://doi.org/ 10.1139/z97-007. 
Miller, R.B., 1952, Survival of hatchery-reared cutthroat trout in an Alberta stream: Transactions of the American Fisheries Society, v. 81, no. 1, p. 35-42, accessed May 13, 2020, at https://doi.org/10.1577/1548-8659(1951)81[35:SOHC TI]2.0.CO;2.

Miller, R.B., 1958, The role of competition in the mortality of hatchery trout: Journal of the Fisheries Research Board of Canada, v. 15, no. 1, p. 27-45, accessed May 13, 2020, at https://doi.org/10.1139/f58-004.

Petrosky, C.E., and Bjornn, T.C., 1988, Response of wild rainbow trout (Salmo gairdneri) and cutthroat trout (S. clarki) to stocked rainbow trout in fertile and infertile streams: Canadian Journal of Fisheries and Aquatic Sciences, v. 45 , no. 12, p. 2087-2105, accessed May 13, 2020, at https://doi.org/10.1139/f88-243.

Seiler, S.M., and Keeley, E.R., 2009, Competition between native and introduced salmonid fishes - Cutthroat trout have lower growth rate in the presence of cutthroat-rainbow trout hybrids: Canadian Journal of Fisheries and Aquatic Sciences, v. 66, no. 1, p. 133-141, accessed October 14, 2020, at https://doi.org/10.1139/F08-194.

Shetter, D.S., 1947, Further results from spring and fall plantings of legal-sized, hatchery-reared trout in streams and lakes in Michigan: Transactions of the American Fisheries Society, v. 74, no. 1, p. 35-58, accessed September 1, 2020, at https://doi.org/10.1577/1548-8659(1944)74[35:FRFS $\mathrm{AF}] 2.0 . \mathrm{CO} ; 2$.

Shetter, D.S., and Hazzard, A.S., 1941, Results from plantings of marked trout of legal size in streams and lakes of Michigan: Transactions of the American Fisheries Society, v. 70, no. 1, p. 446-468, accessed September 1, 2020, at https://doi.org/10.1577/1548-8659(1940)70[446:RFPO MT]2.0.CO;2.

Tipping, J.M., and Serl, J.D., 2000, Lake Scanewa creel census for 2000, Technical report \# FPT 00-32: Olympia, Washington, Washington Department of Fish and Wildlife, $9 \mathrm{p}$.
Trembley, G.L., 1945, Results from plantings of tagged trout in Spring Creek, Pennsylvania: Transactions of the American Fisheries Society, v. 73, no. 1, p. 158-172, accessed August 21, 2020, at https://doi.org/10.1577/1548-8 659(1943)73[158:RFPOTT]2.0.CO;2.

Walters, J.P., Fresques, T.D., and Bryan, S.D., 1997, Comparison of creel returns from rainbow trout stocked at two sizes: North American Journal of Fisheries Management, v. 17, no. 2, p. 474-476, accessed May 13, 2020, at https://doi.org/10.1577/1548-8675(1997)017<0474 :COCRFR $>2.3 . \mathrm{CO} ; 2$.

Ward, D.L., Morton-Starner, R., and Vaage, B., 2018, Are hatchery-reared rainbow trout and brown trout effective predators on juvenile native fish?: North American Journal of Fisheries Management, v. 38, no. 5, p. 1105-1113, accessed May 13, 2020, at https://doi.org/10.1002/ nafm.10216.

Weiland, M.A., and Hayward, R.S., 1997, Cause for the decline of large rainbow trout in a tailwater fishery-Too much putting or too much taking?: Transactions of the American Fisheries Society, v. 126, no. 5, p. 758-773, accessed May 29, 2020, at https://doi.org/10.1577/15488659(1997)126<0758:CFTDOL >2.3.CO;2.

Wiley, R.W., Whaley, R.A., Satake, J.B., and Fowden, M., 1993, Assessment of stocking hatchery trout-A Wyoming perspective: North American Journal of Fisheries Management, v. 13, no. 1, p. 160-170, accessed May 29, 2020, at https://doi.org/10.1577/1548-8675(1993)013<0160 :AOSHTA>2.3.CO;2.

U.S. Geological Survey, 2020, USGS 14233500 Cowlitz River near Kosmos, WA, in USGS water data for the Nation: U.S. Geological Survey National Water Information System database, accessed October 7, 2020, at https://doi.org/10.5066/ F7P55KJN. [Site information directly accessible at https:// waterdata.usgs.gov/nwis/uv?site_no=14233500.]

Zimmerman, C.E., and Reeves, G.H., 2000, Population structure of sympatric anadromous and nonanadromous Oncorhynchus mykiss evidence from spawning surveys and otolith microchemistry: Canadian Journal of Fisheries and Aquatic Sciences, v. 57, no. 10, p. 2152-2162, accessed October 16, 2020, at https://doi.org/10.1139/f00-192. 
Publishing support provided by the U.S. Geological Survey Science Publishing Network, Tacoma Publishing Service Center

For more information concerning the research in this report, contact the

Director, Western Fisheries Research Center

U.S. Geological Survey

6505 NE 65th Street

Seattle, Washington 98115-5016

https://www.usgs.gov/centers/wfrc 
